\title{
KHALIBANA : Karya Musik Absolut Sebagai Wujud Pesan Musik
}

\author{
${ }^{1)}$ Puput Pramuditya \\ Staf Pengajar Prodi Penciptaan Musik \\ Fakultas Seni PertunjukanInstitut Seni Indonesia Yogyakarta \\ puputpramuditya@gmail.com \\ ${ }^{2)}$ Daniel De Fretes \\ Program Studi Musik \\ Fakultas Seni Pertunjukan Institut Seni Indonesia Yogyakarta \\ danieldefretes@isi.ac.id
}

\begin{abstract}
Abstrak
Musik memiliki persamaan dengan unsur bahasa, yaitu terdapatnya sebuah pesan dengan intonasi dan derajat ekspresi tertentu bagi pendengarnya. Dalam karya musik programa, pesan tersebut merupakan sebuah hal ekstramusikal dari sebuah peristiwa atau tokoh yang bertransformasi menjadi bunyi bagi pendengarnya. Berbeda dengan musik programa, pesan dalam musik absolut berasal dari musik itu sendiri yang akan bertransformasi menjadi persepsi-persepsi tertentu dalam pikiran pendengarnya. Karya musik 'Khalibana' berasal dari gagasan tentang fenomena pesan dalam musik absolut yang tidak menggiring pendengarnya menuju persepsi ekstramusikal tertentu sehingga kebebasan impresi menjadi kemerdekaan bagi pendengarnya. Karya musik 'Khalibana' disusun dengan pengolahan kontur nada sebagai pembentuk melodi utama karena kontur nada merupakan hal yang berkaitan erat dengan intonasi dalam bahasa. Karya ini dimainkan dengan formasi piano dan cello serta mempunyai 4 bagian yang berbeda satu sama lain.
\end{abstract}

Kata kunci: pesan musik, musik absolut, kontur nada

\begin{abstract}
Music has similarities with language elements, namely the presence of a message with a certain intonation and degree of expression for the audience. In program music, the message is an extramusical thing of an event or character that is transformed into a sound for the audience. Unlike program music, the message in absolute music comes from the music itself which will be transformed into certain perceptions in the minds of the audience. The music composition 'Khalibana' originates from the idea of a message phenomenon in absolute music which does not lead the listener to certain extramusical perceptions so that freedom of impression becomes freedom for the listener. The music composition 'Khalibana' is composed by processing tone contours as the main melody constituents because the tone contours are closely related to intonation in language. This piece is played in piano and cello formations and has 4 different parts.
\end{abstract}

Keywords: musical message, absolute music, tone contours 


\section{A. Pendahuluan}

Persepsi atau ungkapan bahwa musik mengandung sebuah pesan untuk disampaikan kepada pendengarnya sering kita dengar. Pesan tersebut sejatinya dapat dimaknai sebagai unsur musikal maupun ekstramusikal dari sebuah karya musik. Apabila musik mempunyai sebuah unsur pembentuk dari luar dirinya atau disebut dengan istilah ekstramusikal, maka musik tersebut masuk ke dalam jenis musik programa. Jika musik tidak mempunyai hal lain selain unsur musikal sebagai pembentuk musik, maka musik tersebut masuk ke dalam jenis musik absolut. Musik absolut dan musik programa sejatinya bukan suatu dikotomi yang harus diperdebatkan karena sebenarnya baik musik programa maupun musik absolut adalah soal sejauh mana musik dapat bercerita yang penangkapannya berdasarkan opini pendengarnya (Ammer, 2004).

Membahas pesan dalam musik programa dan musik absolut, hakekat keduanya mirip dengan sebuah bahasa. Dalam essainya yang berjudul 'Music, Language, and Composition' Theodor Adorno mengatakan bahwa musik sama dengan bahasa walaupun musik bukan bahasa dan kesamaannya dengan bahasa menunjukkan sifatnya yang paling dalam. Bahasa merupakan sebuah pesan yang memiliki intonasi, takaran waktu, dan derajat ekspresi yang dapat memberikan impresi tertentu bagi pendengarnya. Perbedaannya dengan musik ada pada wujud pesan yang diterima oleh pendengar. Jika bahasa mempunyai pesan dalam bentuk yang jelas walaupun maknanya bisa jadi tidak tunggal karena persoalan aspek intonasi, sedangkan musik memiliki pesan dalam wujud musik itu sendiri yang memang berasal dari bunyibunyian secara absolut atau dari sebuah hal ekstramusikal yang ditransformasikan dalam bunyi-bunyian, kemudian diterima oleh pikiran pendengar sehingga bertransformasi menjadi persepsi-persepsi tertentu yang berpotensi mengalami perbedaan impresi pada tiap pendengarnya.

Melodi dalam musik programa diciptakan berdasar imajinasi komponis untuk mewakili atau menggambarkan suatu tokoh, suasana, atau karakter berdasarkan sebuah peristiwa (Hasibuan, 2019). Berbeda dengan musik programa, musik absolut merupakan sebuah musik yang tidak memiliki tendensi apapun terhadap hal di luar musik itu sendiri sehingga dalam proses penciptaannya tentu tidak ada sebuah kesan atau nuansa yang dibuat untuk menggambarkan atau menceritakan suatu hal yang bersifat ekstramusikal. Dalam perkembangannya, musik programa lebih banyak diminati karena dianggap lebih mudah untuk dinikmati dan 
ditangkap pesannya lewat sebuah program notes ataupun penjelasan langsung dari komposernya daripada musik absolut yang tidak memiliki unsur cerita sehingga dianggap lebih sulit untuk dipahami. Perbedaan yang pokok antara konsep pada musik programa dengan absolut memberikan sebuah ruang yang seringkali digarap pada tataran penciptaan.

Fenomena tersebut memunculkan sebuah gagasan bahwa terdapat kesamaan antara musik dengan bahasa. Musik yang jika disusun dengan konsep-konsep tertentu niscaya akan menjadi sebuah pesan yang dapat ditangkap oleh pendengarnya. Gagasan tersebut memunculkan sebuah ide penciptaan karya musik 'Khalibana', yaitu karya musik absolut yang disusun dengan bentuk free form sesuai dengan kaidah musik absolut yang tidak terikat oleh sebuah cerita atau unsur ekstramusikal dalam proses pengolahan musiknya.

\section{Seputar Musik Absolut}

Musik absolut secara penuh mempunyai sebuah pesan musik tanpa ada muatan yang bersifat ekstramusikal. Ide penciptaan dalam karya musik absolut bukanlah sebuah cerita, tokoh, atau peristiwa namun tema-tema musik yang dapat dikembangkan dengan pertimbangan- pertimbangan musikal. Musik absolut juga merupakan sebuah musik yang bebas dan tidak mempunyai tendensi apapun terhadap pengaturan tensinya. Jika di dalam musik programa telah ditentukan sebuah cerita tertentu sebagai ide penciptaannya maka komposer tidak akan bisa melepaskan diri dari emosi yang terkandung dari cerita tersebut sehingga tensi dalam karya musik pasti akan terbelenggu oleh unsur ekstramusikalnya dalam kadar tertentu. Setiap kesadaran akan mengurangi pengaruh emosi dalam musik. Maka orang yang secara sadar mengetahui unsur ekstramusikal dalam sebuah karya musik akan merespon dengan pengetahuannya terhadap unsur cerita dalam musik tersebut. Lain halnya dengan orang yang tidak memiliki gambaran apapun terhadap musik yang didengarnya akan lebih dapat merespon melalui intuisi dan emosinya tanpa ada kecenderungan apapun. Hal ini menunjukkan bahwa orang yang tidak mempunyai gambaran apapun terhadap unsur cerita dalam musik akan lebih dapat berkesan daripada orang yang telah mengetahui unsur cerita di dalam musik (Myers, 2002).

\section{Kreatifitas}

Setiap manusia akan banyak dipengaruhi oleh segala sesuatu yang berasal dari luar dirinya. Buku-buku yang pernah dibaca, diskusi dengan orang lain, pengalaman 
sehari-hari, serta sesuatu yang didengarnya. Namun yang diharapkan dari seorang seniman tentu saja adalah orisinalitasnya, yaitu adanya aspek kreativitas individualnya yang memunculkan orisinalitas sehingga bisa ditangkap dan diapresiasi oleh orang lain. Pada tataran akademi, kreativitas dapat membawa kepada penemuan ilmiah baru, gerakan baru dalam bidang seni, dan lain sebagainya (Iswantara, 2017). Manusia dikaruniai kekuatan kreasi yang hampir tidak berbatas, walaupun tentu saja kadar kemampuan kreativitas setiap manusia pasti akan berbeda-beda antara satu dengan yang lainnya.

Karya 'Khalibana' berangkat dari sebuah fenomena ketiadaan unsur ekstramusikal dalam musik absolut sehingga musik menempatkan dirinya secara mandiri masuk ke pendengaran manusia hingga bertransformasi menjadi persepsi-persepsi tertentu yang mungkin akan berbeda pada setiap pendengarnya. Hal ini mermunculkan sebuah ide penciptaan tentang sebuah musik absolut yang tidak terikat secara harmoni maupun melodinya dengan tangga nada tertentu. Tangga nada adalah sebuah jalur titian nada yang mempunyai sebuah nada sebagai porosnya. Dalam karya 'Khalibana', hal ini justru dihindari agar pesan yang ditangkap oleh pendengar tidak tergiring oleh sebuah titian nada sebagai melodi ataupun harmoni. Sebagai konsep untuk membentuk melodi, digunakan beberapa jenis kontur untuk membentuk sebuah melodi yang terbebas dari kaidah tangga nada tertentu.

Judul karya musik ini diambil dari 2 kata, 'Khali' dan 'Bhana'. 'Khali' dalam KBBI berarti bebas, lepas, sedangkan 'Bhana' berarti bahana atau bunyi, jadi 'Khalibhana' berarti bunyi yang terlepas. Terlepas dimaksudkan bahwa karya ini tidak terikat oleh tempo, terlepas dari struktur tradisional, dan menghindari tonal, namun masih berkedudukan jelas pada fungsi tiap-tiap instrumennya. Keterlepasan ini juga dimaknai sebagai sebuah simbol bahwa musik bisa berdiri sendiri menjadi sebuah pesan dan tidak terikat pada unsur cerita tertentu di luar musik itu sendiri.

\section{Konsep Melodi dan Harmoni}

Pengolahan melodi dan harmoni dalam karya ini menggunakan sebuah konsep yang dibentuk dari fakta kontur intonasi pada sebuah bahasa karena intonasi dalam sebuah bahasa merupakan wujud ekspresi dari pengucap yang dapat menentukan makna dari sebuah kalimat. Intonasi mempunyai dua fungsi utama yaitu fungsi gramatikal atau fungsi primer dan fungsi emosional. Fungsi emosional memiliki andil yang penting bagi makna emosi orang yang berbicara, karena jika pembicara mengubah intonasi dalam 
kalimatnya, maka intonasi tersebut dapat pula mengubah aspek emosi dalam kalimatnya (Halim, 1984). Intonasi juga memiliki makna nonlinguistik, dalam hal ini bisa ditemukan dalam durasi atau kecepatan orang berbicara yang dapat mencerminkan karakter atau sikap seseorang yang sedang berbicara (Lehiste, 1970).

Dalam karya ini, aspek intonasi pada bahasa diterjemahkan ke dalam sebuah konsep untuk membentuk melodi dalam tiap-tiap bagiannya. Konsep kontur sebagai pembentuk melodi diterapkan dengan tidak memberi batasan melodi dengan tangga nada atau interval tertentu. Batasan dalam pengolahan melodi hanya didasarkan pada bentuk kontur yang telah direncanakan. Pembentukan kontur difokuskan menjadi 5 jenis kontur melodi yang asimetris seperti pada tabel 1. Konsep kontur yang akan dipakai di dalam karya 'Khalibana' merupakan gerakan melodi naik dan turun namun tidak dibuat dengan simetris untuk menghindari sebuah gerakan melodi yang teratur. Pemilihan kontur dilakukan secara arbitrer dengan mempertahankan aspek asimetri.

\begin{tabular}{|l|l|}
\hline Nama & Bentuk \\
\hline Kontur 1 & \\
Kontur 2 & \\
Kontur 3 & \\
Kontur 4
\end{tabular}

Tabel 1

Kontur sebagai pembentuk melodi

Harmoni dalam karya ini tidak memiliki konsep yang benar-benar direncanakan secara sengaja. Harmoni yang muncul dalam karya ini merupakan gerakan vertikal yang terbentuk sebagai akibat dari adanya gerakan horizontal melodi di tiap-tiap konturnya. Hal ini dilakukan berdasarkan ide penciptaan untuk menyusun karya musik yang 
terlepas dan bebas dari bentuk baku (free form). Konsep penyusunan melodi dan harmoni seperti yang telah dikemukakan di atas dijadikan landasan utama sebagai pembentuk kalimat dalam karya ini. Pengolahan lain dalam karya musik ini akan menggunakan teknikteknik umum komposisi musik yaitu ekstensi dan kontraksi dalam penyusunan kalimat musik. Penyusunan ritme dilakukan secara arbitrer dengan memperhatikan keseimbangan kontur naik dan turun dalam sebuah kalimat musik.

\section{B. Metode Penelitian Penciptaan}

Setiap karya musik pasti mempunyai subyektifitas yang melekat dari komposernya dan setiap seniman memiliki cara atau prosedur tersendiri dalam menyusun karya sesuai kebiasaannya (Handayani, 2018). Subyektifitas tersebut terdiri dari hal yang sangat mendasar sebagai bekal dasar dalam berkreasi yaitu imajinasi dan intuisi. Hadirnya 2 hal tersebut bukan berarti metode penciptaan karya musik tidak dapat dijelaskan secara logis karena dalam pembuatan karya musik 'Khalibana' tetap mengandung rasionalitas yang dapat dijelaskan secara ilmiah. Proses penciptaan dimulai dari pengumpulan data-data terkait musik absolut yang berbentuk audio-video, score, dan pustaka yang berisi data sejarah dan teknik komposisi musik. Data-data ini kemudian diobservasi dengan membedah dan menganalisis secara auditif untuk karya-karya audio-video dan analisis teks pada score yang telah didapatkan. Pada tahapan ini juga dilakukan pencocokan terhadap data sejarah terkait dengan karya musik.

Tahapan selanjutnya diadaptasi dari metode penciptaan tari yang diharapkan dapat menjadi sumbangsih pengembangan kreatif yaitu eksplorasi, improvisasi, dan komposisi (Hawkins, 1988). Masing-masing klasifikasi dalam tahapan ini dilakukan dengan porsi yang seimbang dan proses yang sedalam mungkin karena tahapan ini merupakan pangkal dari proses penciptaan karya musik. Eksplorasi dilakukan dengan cara berpikir kritis terhadap ide penciptaan yaitu membuka berbagai kemungkinan bunyi terhadap ide penciptaan hingga mengimajinasikan bentuk-bentuk bunyi dalam alam pikiran. Proses ini berbeda dengan improvisasi yang cenderung untuk memunculkan 'sesuatu' dari dalam diri sendiri dengan tindakan spontanitas, eksplorasi biasanya mempunyai panduan dari luar sebagai pemantik ide seperti karya-karya terdahulu dan data sejarah untuk memberi batasan karena ini merupakan tahapan awal dalam menyusun komposisi musik.

Tahapan selanjutnya adalah dengan proses improvisasi yaitu kegiatan yang 
memberikan keleluasaan bagi diri sendiri untuk melakukan percobaan berdasar hasil eksplorasi tanpa ada batasan apapun. Keleluasaan ini dilakukan untuk memunculkan karakter 'inner' untuk merespon hasil eksplorasi. Berbagai tindakan musikal spontan dimunculkan dalam proses improvisasi untuk memacu aktivitas kreatif. Kreativitas melalui improvisasi terkadang diartikan seperti 'terbang ke yang tak diketahui' dan itulah saat yang tepat bagi seorang komposer untuk menggunakan simpanan imaji-imajinya dan mengeluarkannya dalam bentuk yang baru (Hawkins, 1988).

Proses tahapan selanjutnya adalah komposisi dilakukan sebagai puncak dari segala proses yang telah dilakukan sebelumnya. Proses ini merupakan proses pengitegrasian dari reduksi ide penciptaan yang telah mengalami proses eksplorasi dan improvisasi. Tahapan ini membutuhkan kendali penuh oleh komposer untuk menyatukan berbagai hal yang telah dilakukan dalam proses sebelumnya. Dalam hal ini lazim dilakukan penyesuaian ulang terhadap konsep-konsep musikal dengan berbagai pertimbangan artistik. Setelah tahapan komposisi dilakukan maka tahapan terakhir adalah finalisasi. Finalisasi adalah kegiatan pemeriksaan kembali sebelum karya dimainkan. Hal ini dianggap perlu karena terdapat banyak potensi komposer melakukan kesalahan di tempat-tempat tertentu sehingga proses pemeriksaan kembali ini dapat dilakukan untuk meminimalisir kesalahankesalahan teknis yang dilakukan komposer. (Tabel.2)

\begin{tabular}{|c|l|l|}
\hline No & \multicolumn{1}{|c|}{ Tahapan } & \multicolumn{1}{c|}{ Keterangan } \\
\hline 1 & Pengumpulan Data & Data Audio-Video, Score, Buku (teknik dan data sejarah) \\
\hline 2 & Observasi & Analisis auditif teks dan konteks \\
\hline 3 & Eksplorasi & Pengembangkan ide penciptaan \\
\hline 4 & Improvisasi & Pemunculan 'inner' untuk merespon hasil eksplorasi \\
\hline 5 & Komposisi & Pembentukan dan penyatuan dari hasil semua proses \\
\hline 6 & Finalisasi & Pemeriksaan kembali \\
\hline
\end{tabular}

Tabel 2

Tahapan Metode Penelitian dan Penciptaan 


\section{Hasil dan Pembahasan}

Karya musik 'Khalibana' dimainkan dengan formasi duet Piano dan Cello untuk menempatkan instrumen secara efisien dalam hal orkestrasi dan teknik permainannya. Piano dan Cello dipilih juga karena alasan keluasan ambitus yang dimiliki oleh keduanya sehingga komposer mempunyai keleluasaan terhadap pengolahan dan pengelolaan register instrumentdalam tiap-tiap bagian karya ini. Tidak seperti karya musik dengan bentuk tertutup seperti sonata, concerto, atau symphony yang mempunyai perluasan tema dengan bagian pengulangan, dalam karya ini 4 bagian utama yang menjadi pembentuk tidak mempunyai pengulangan tema di tiaptiap bagiannya. Bagian A merupakan introduksi yang disusun menggunakan kontur 1, 2, dan 3 sebagai material utamanya. Ketiga kontur disusun dengan menghindari kualitas interval mayor dan menggunakan jarak yang melompat-lompat untuk menghindari munculnya kecenderungan terhadap poros nada seperti dalam tangga nada diatonis.

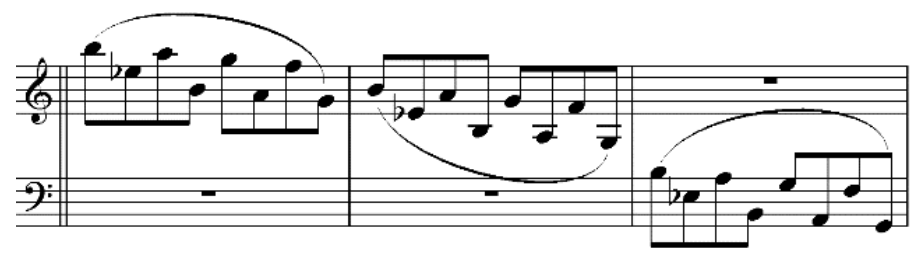

Gambar 1

Motif dalam bagian introduksi dari kontur 1

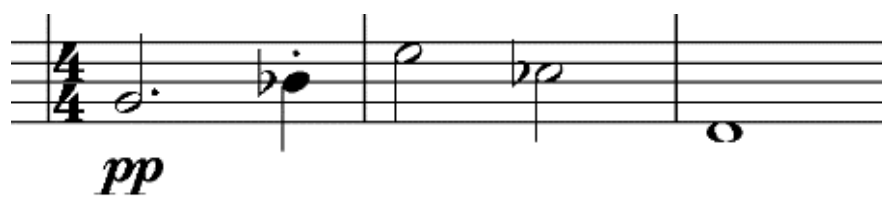

Gambar 2

Motif dalam bagian introduksi dari kontur 2

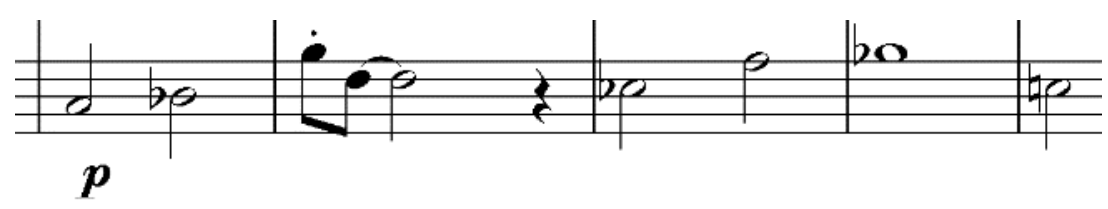

Gambar 3

Motif dalam bagian introduksi dari kontur 3 
Pada bagian A instrumen piano memainkan motif-motif tanpa didampingi oleh instrument cello. Instrument cello baru membunyikan nada di bagian $\mathrm{B}$, hal ini untuk memberi efek kontras terhadap warna dan tensi musikal mengingat bahwa karya ini hanya menggunakan 2 instrumen sebagai media pewujud konsep bunyi.Dalam bagian ini pula terdapat motif aksen untuk menambah kesan keterlepasan dari karya ini. Terdapat akor dengan 3 nada berdurasi pendek dan 1 nada paling atas dengan durasi yang panjang seperti pada gambar 4. Pemunculan motif ini mengasosiasikan sebuah nada yang terlepas dari kelompok akornya yang ditandai dengan ritme yang berbeda oleh 1 nada paling atas.

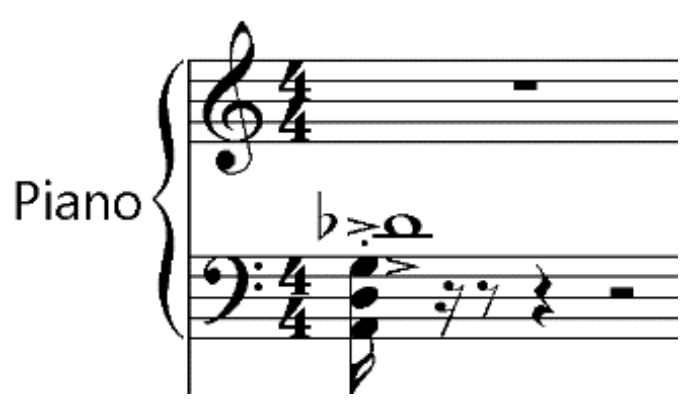

Gambar 4

Akor dengan ritme asimetris pada bagian A

Bagian A disusun dengan dasar ritme yang renggang dan dinamika piano untuk membuat sebuah bagian pembuka karya. Hal ini lazim dipakai dalam karya-karya musik dari zaman klasik. Namun setelah ritme dan dinamika tersebut disusun, dapat dirasakan bahwa terdapat momentum yang hilang pada bagian-bagian tertentu sehingga dilakukan penyisipan motif-motif yang diambil dari material kontur dengan ritme-ritme rapat dan dinamika forte agar terdapat keragaman warna dalam karya musik ini
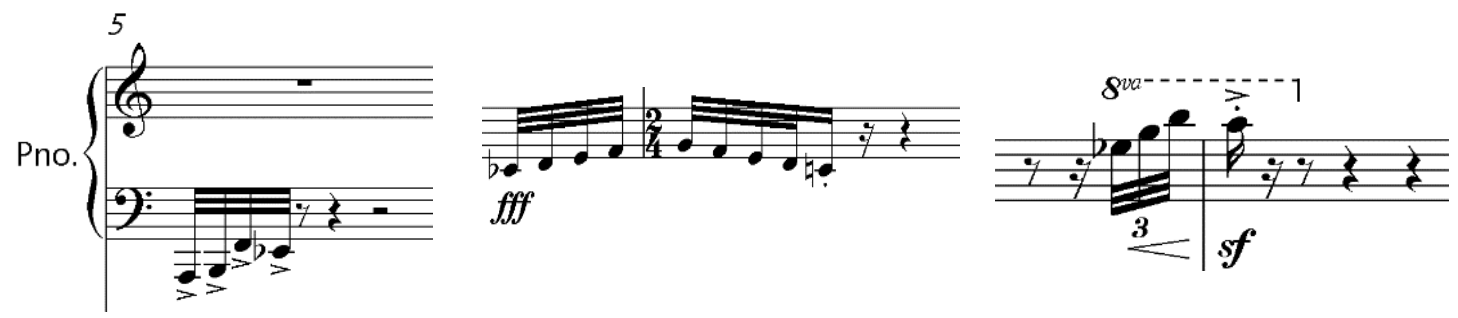

Gambar 5

Beberapa sisipan motif baru di bagian A 
Pada bagian B tetap dipertahankan tempo moderato dan disusun hanya dengan kontur 3. Bagian ini hanya terdiri dari $10 \mathrm{bar}$ dengan variasi pengolahan motif pada kontur. Akor dengan ritme asimetris seperti di bagian A dimunculkan sebagai pembuka bagian B dan dimulai dengan penyusunan kontur 3 yang dipotong menjadi beberapa figur dan ditempatkan di instrumen cello maupun piano secara acak untuk menimbulkan nuansa baru yang berbeda dari bagian A sehingga audiens merasa terdapat motif baru. Pemunculan ritme triplet juga diharapkan dapat mengaburkan nuansa dari bagian A sehingga bagian B tampak seperti bagian yang berbeda dari bagian $\mathrm{A}$.

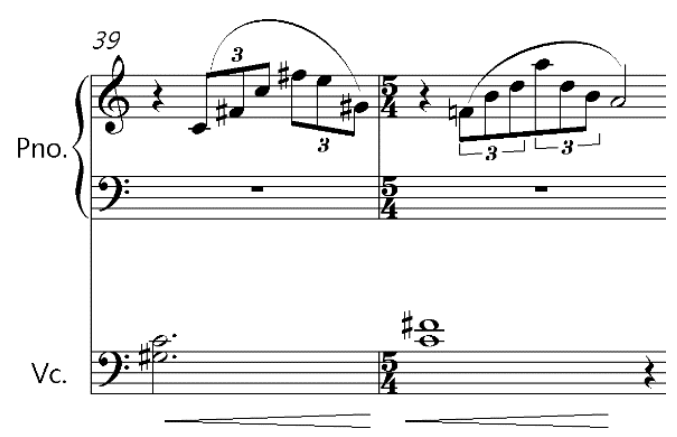

Gambar 6

Triplet pada bagian B dengan motif kontur 3

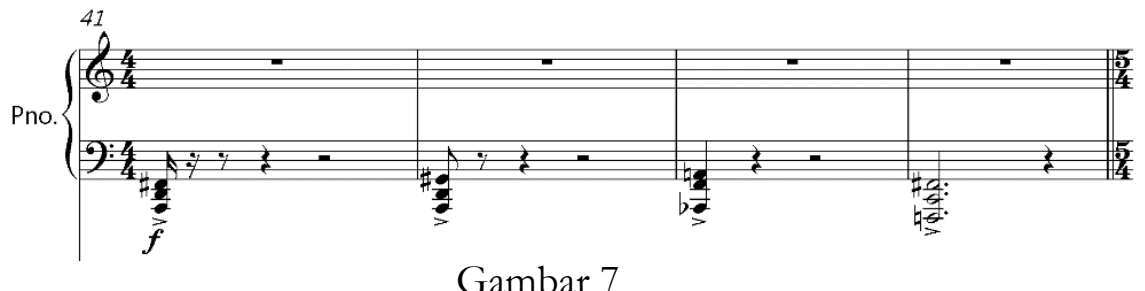

Transisi menuju bagian $\mathrm{C}$

Terdapat transisi 4 bar dari bagian $\mathrm{B}$ menuju bagian $\mathrm{C}$ menggunakan akor yang dimainkan dengan durasi yang semakin panjang di tiap biramanya sebagai persiapan untuk menuju perubahan tempo yang semakin cepat di bagian C. Di bagian C, 
kontur 5 banyak dimunculkan untuk mengikuti kontur 4 sebagai aksen dalam membuat suasana baru yang berbeda dari sebuah tema. Pengolahan kontur 5 juga bagian-bagian sebelumnya. Pada bagian tertentu, cello diberikan instruksi untuk memainkan pola nada yang bebas namun dilakukan dengan dilakukan pemotongan motif secara acak dengan teknik interlocking ritme

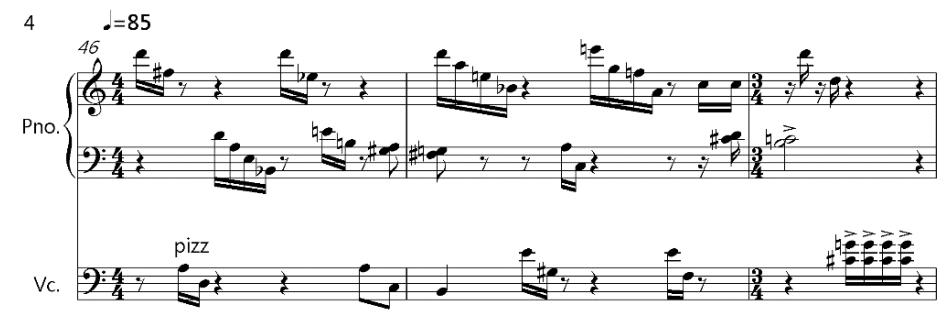

Gambar 8

Interlocking pada bagian $\mathrm{C}$

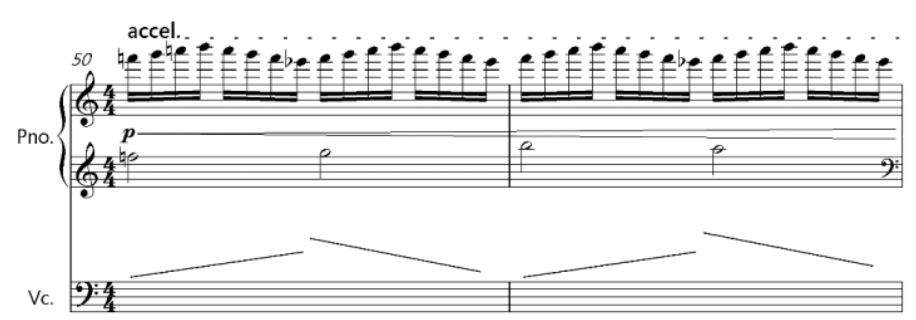

Gambar 9

Pola kontur 4 untuk instrument cello

Sebagai penguat keterlepasan dari harmoni konvensional, dimunculkan pula akor cluster sebagai transisi menuju bagian D. Hal ini dilakukan untuk menaikkan tensi dalam bangunan tekstur bunyi yang telah mencapai dinamika keras. Bagian ini diakhiri dengan piano yang memainkan arpeggio dengan dinamika crescendo untuk mengakhiri tensi dan dinamika yang terjadi di bagian C. Dalam penyusunan sebuah karya musik diperlukan strategi pengaturan tensi untuk mendapatkan momentum yang diharapkan dapat tertangkap oleh pendengarnya sebagai sebuah pesan bunyi. Bagian D merupakan bagian penurunan tensi yang disusun dengan tempo largo setelah tensi yang semakin naik di bagian sebelumnya. Disusun dengan ritme yang renggang dan dinamika piano. Pengulangan motif yang dilakukan oleh piano dalam bar 6974 mengadaptasi teknik dalam musik minimal 
Puput Pramuditya, Daniel De Fretes (Khalibana..) pp.51-64

walaupun instrumen cello memainkan tema dari kontur 3 dalam berbagai jenis ritme dan diakhiri dengan munculnya akor asimetris seperti pada bagian A dan B.
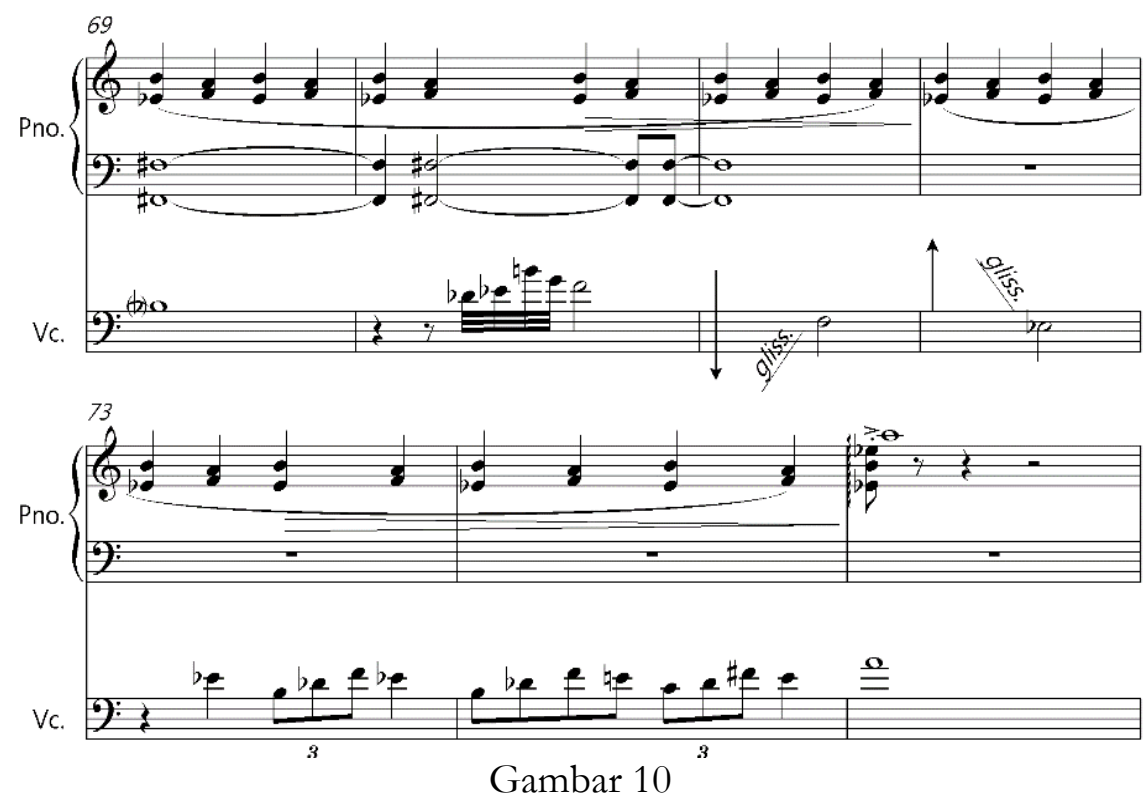

Teknik minimal oleh piano direspon cello dengan motif kontur 3
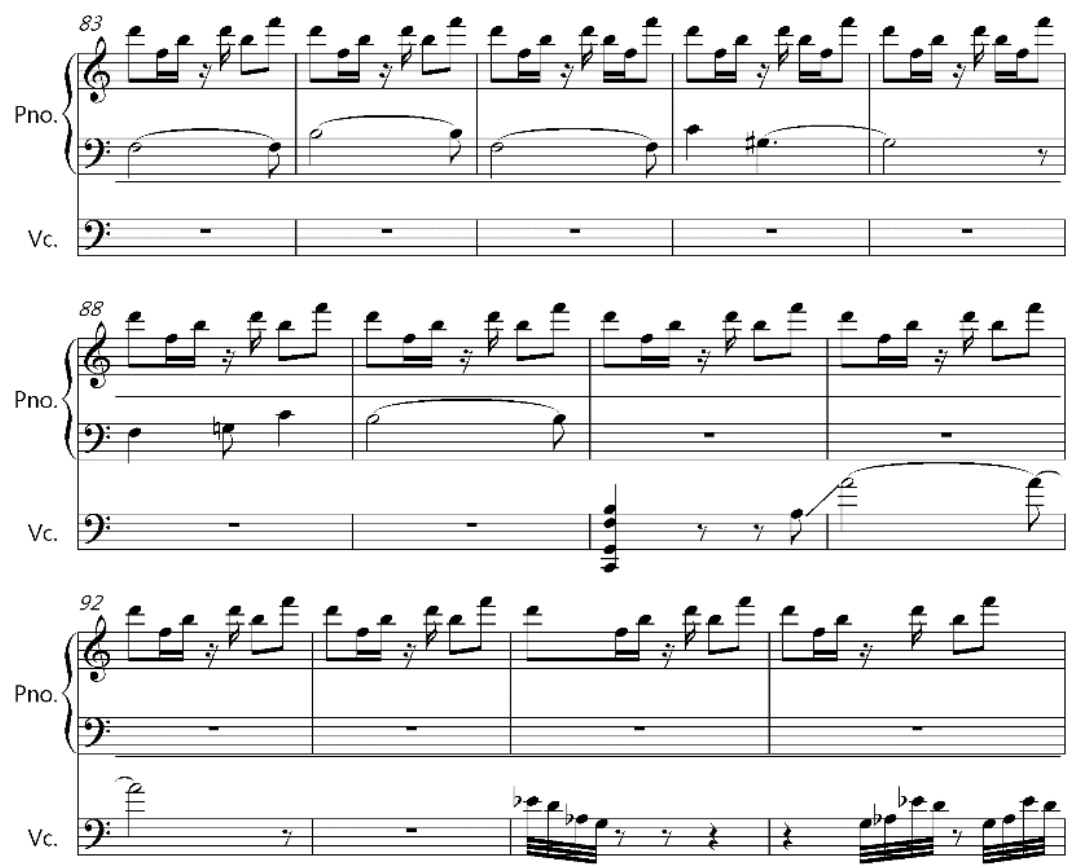

Gambar 11

Semua kontur merespon teknik minimal dari kunci $G$ piano 
Teknik minimal ini dimunculkan kembali dalam bar 80-104 oleh piano dalam kunci $G$, sedangkan kunci $F$ piano dan cello merespon dengan motif kontur 1, 2, 3, 4, dan 5 dengan ritme renggang hingga ritme yang rapat seperti dalam gambar 11. Sebagai coda dari karya ini disusun teknik unisono untuk piano dan cello untuk memberi kejutan momentum dalam suasana minimalis dengan kontur 2 dan 3. Coda ini disusun dengan tempo vivace dan dinamika yang sangat keras untuk memberi kontras pada tempo sebelumnya agar kejutan momentum dapat tertangkap secara maksimal seperti pada gambar 12 .

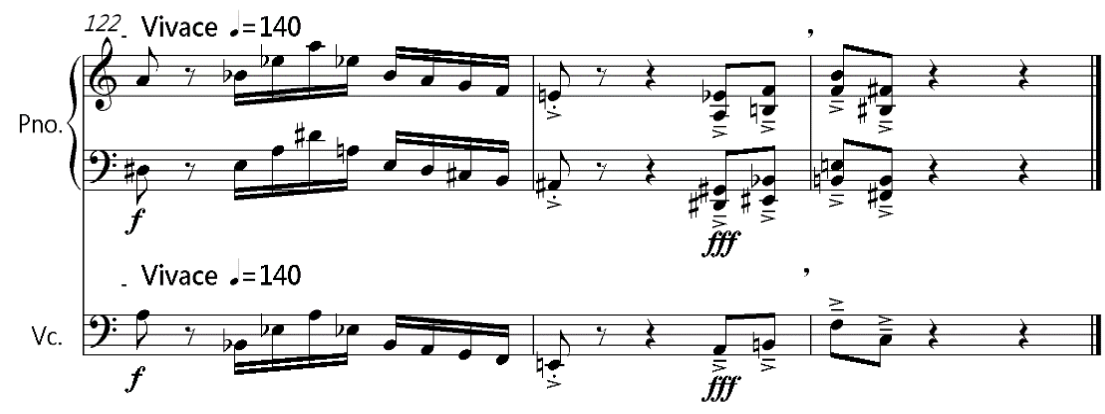

Gambar 12

Coda dari kontur 2 dan 3 dengan unison

\section{Simpulan}

Proses penciptaan musik 'Khalibana', sejak munculnya gagasan sebagai pemicu ide penciptaan hingga bertransformasi menjadi sebuah bunyi ditemukan beberapa hal krusial sebagai hasil akhir dari sebuah proses penciptaan musik. Kesimpulan sebagai akhir dari sebuah proses penciptaan karya ini menunjukkan bahwa jalinan nada-nada memiliki kemampuan untuk menggiring dirinya sendiri untuk memunculkan momentum musikal dalam sebuah karya musik sehingga diperlukan penyesuaian terhadap konsep musik dalam proses penyusunan karya untuk mewujudkan kesan keindahan. Hasil temuan dalam proses penciptaan ini juga menunjukkan bahwa musik dapat kehilangan momentum tersebut karena komponis bersikap kaku terhadap sebuah konsep musik. Proses penciptaan musik absolut yang tidak mempunyai kecenderungan untuk menerjemahkan sesuatu di luar dirinya mengakibatkan prosesnya dapat berjalan sangat mengalir dan 
lentur sehingga tiap nada dalam kalimat musik seakan mengarahkan dirinya sendiri untuk mendapat sebuah kesan musik yang indah.

Dalam proses penciptaan music absolut, kelenturan komposer untuk mengikuti jalinan nada-nada tersebut terkadang mengakibatkan ide yang keluar menjadi tidak terbendung. Hal yang selalu harus diingat adalah bahwa setiap karya seni pasti mempunyai sebuah konsep yang menjadi benang merah sehingga composer tetap harus memberi batasan terhadap ide yang muncul di pikirannya. Penggunaan 2 instrumen, piano dan cello dalam karya ini juga menuntut sebuah kecermatan dan efisiensi untuk mewujudkan konsep musik dengan warna suara yang terbatas. Keterbatasan timbre mengharuskan penyusunan dinamika, tensi, dan tekstur karya musik harus selalu menjadi pertimbangan untuk menghasilkan sebuah natural balance.

\section{E. Daftar Pustaka}

Ammer, Christine, 2004. The Facts On File: Dictionary of Music. New York: Facts On File, Inc.

Halim, Amran, 1984. Intonasi dalam Hubungannya dengan Sintaksis Bahasa Indonesia. Jakarta: Djambatan.

Handayani, Nur, 2018. "Proses Penciptaan Musik Suara Sindhen: Interpretasi Gendhing Ginonjing Karya Nur Handayani". Gelar: Jurnal Seni Budaya. Vol 16, No 1.

Hasibuan, Herindra, 2019. "Melodius: Karya Musik Absolut". Jurnal Pendidikan dan Pembelajaran Khatulistiwa. Vol 8, No 10.

Hawkins, Alma M., 2003. Mencipta Lewat Tari. Terjemahan dari Creating Through Dance. Yogyakarta: Manthili.

Iswantara, Nur, 2017. Kreativitas: Sejarah, Teori \& Perkembangan. Yogyakarta: Gigih Pustaka Mandiri.

Lehiste, Ilse, 1970. Suprasegmentals. United States of America: The Colonial Press, Inc.

Myers, David G., 2002. Intuisi: Fungsi Insting dan Naluri untuk Meraih Kesuksesan. Terjemahan dari Intuition: The Power and Perils. Yogyakarta: Penerbit Qalam. 